\title{
Bank Risk Profile and Credit Growth in Indonesia
}

AFFILIATION:

1,2,3,4 Faculty of Economics, Universitas Negeri Jakarta, Indonesia

${ }^{5}$ Faculty of Economics, Universitas Negeri Semarang, Indonesia

*CORRESPONDENCE:

herakhairunnisa@unj.ac.id

THIS ARTICLE IS AVAILABLE IN:

https://ojs.unud.ac.id/index.php/jiab

DOI:

10.24843/JIAB.2021.v16.i01.p06

CITATION:

Gurendrawati, E., Khairunnisa, Hera., Ulupui, I. G. K. A., Zakaria, A., \& Suryarini, T. (2021). Bank Risk Profile and Credit Growth in Indonesia. Jurnal Ilmiah Akuntansi dan Bisnis, 16(1), 84-95.

\section{ARTICLE HISTORY}

Received:

04 November 2020

Revised:

28 December 2020

Accepted:

08 January 2021

\author{
Etty Gurendrawati ${ }^{1}$, Hera Khairunnisa ${ }^{2 *}$, I Gusti Ketut Agung Ulupui ${ }^{3}$, \\ Adam Zakaria ${ }^{4}$, Trisni Suryarini ${ }^{5}$
}

\begin{abstract}
Banks are one of the important industries in a country, whose importance is evidenced by the management of bank risks. The purpose of this research is to investigate the effect or impact of the risk profile disclosure on banking credit growth in Indonesia. Commercial banks in Indonesia, which provide information related to a complete risk profile in the annual report from 2016-2018, were selected as the sample. The risk profile variable is an independent variable consisting of credit risk, market risk, and liquidity risk. Panel data regression with E-Views 8 was used for data processing. The results of the study prove that disclosure of credit risk, market risk, and liquidity have significant influences to the banking credit growth in Indonesia.
\end{abstract}

Keywords: risk profile, credit growth, credit risk, market risk, liquidity risk

\section{Introduction}

In 2018, the condition of global economic growth went slowdown in general (Otoritas Jasa Keuangan, 2018b). The slowdown in the global world economy was marked by tightening liquidity due to an increase in the benchmark interest rate of the United States (US), an increase in the intensity of the trade war between the US and China, and rising oil prices as a result of US sanctions on Iran.

The global economic slowdown has not hampered domestic economic growth because the level of investment and domestic consumption is still strong (Otoritas Jasa Keuangan, 2018b). In line with the strengthening of investment and domestic consumption, the banking credit business has also increased, although not accompanied by an increase in third-party funds (Otoritas Jasa Keuangan, 2018b).

The global economy also has no significant impact on the existence of commercial banks in Indonesia. The growth of commercial banks in Indonesia was relatively stable from 2014 to 2018. The number of commercial banks in 2014 was 119 banks, in 2015 there were 118 banks, in 2016 there were 116 banks, in 2017 there were 115 banks, and in 2018 there were 115 banks (Otoritas Jasa Keuangan, 2018b).

Based on the banking survey in Quarter III 2018 from Bank Indonesia, it is stated that the growth of third party funds is expected to 


\section{Gurendrawati, Khairunnisa, Ulupui, Zakaria, Suryarini}

Bank Risk Profile and Credit Growth in Indonesia

increase in the fourth quarter of 2018. The Bank Indonesia Banking Survey also indicated that the quarterly growth of new loans tended to slow down in quarter III-2018. From the Bank Indonesia survey, information was also obtained that the tightening of lending will be mainly carried out on investment credit and working capital credit, namely in the aspects of the credit ceiling, risky credit premium and credit extension period.

Management of banking operational activities cannot be separated from the banking risk management process. Banking risk management is required due to the rapid development of the internal and external banking environment. The rapid development of the external and internal environment also forces banks in Indonesia to implement good governance (Otoritas Jasa Keuangan, 2018a). The importance of risk management has made regulators formulate various regulations to ensure that banks in Indonesia can manage the risks involved in achieving their goals.

The risks faced by the banking sector include credit risk, market risk, liquidity risk, operational risk, compliance risk, legal risk, reputation risk, and strategic risk. Banking risk management will affect the soundness level of the banking system because Bank Indonesia assesses banking performance based on risk management for the bank (Peraturan Bank Indonesia Nomor: 13/ 1 /PBI/2011, 2011). Banks in Indonesia must assess the risks they face and these banks are obliged to publish their risk profiles in their financial reports. The presentation of the risk profile provides transparency on banking performance which is useful for stakeholders such as debtors, investors, and others.

The Financial Services Authority / OJK has certain measurement criteria to assess the performance of banks in Indonesia. The bank's performance measures include total assets. Total assets, namely the number of total assets of a bank including loans extended by banks and other assets. Another measure of performance is the number of sources of funds in the form of nominal third party funds which represent the bank's ability to raise funds from third parties. Another banking performance is also measured through the use of funds which includes performance measurement in the form of gross Non-Performing Loan (NPL) ratios and net NPL ratios, both ratios measure the rate of return on bank loans that have been disbursed. Another ratio that is used as a measure of banking performance is the Loan to Deposit Ratio (LDR) which is a ratio to measure the level of bank liquidity in meeting its obligations.

The risk profile is one of the indicators used by investors as one of the stakeholders to assess the condition of the company (Khairani \& Dillak, 2018). However, research proves that the risk profile does not have a significant effect on stock returns (Ayem \& Wahyuni, 2017; Khairani \& Dillak, 2018). NPL does not affect stock returns because when the NPL of banks in Indonesia increased, many investors decided not to sell their shares. The absence of a significant effect of NPL on the rate of return on shares is because the bank has a high adequacy rate that exceeds that determined by the regulator so that capital adequacy helps cover credit risk caused by bad credit. In contrast to research in Indonesia, research in Turkey produces evidence that if a bank can manage credit risk well, the bank will get a low level of bad credit, a low level of bad credit helps banks to keep growing (Ekinchi, 2016). Banks financial risk management affect bank performance or profitability (Wanjohi, 2017).

The risk profile is also an indicator used by investors to assess the level of profitability of banks in Indonesia. Credit risk, market risk, liquidity risk, and operational risk affect bank profitability (Fahrul \& Rusliati, 2018). Meanwhile, credit risk has no 


\section{Gurendrawati, Khairunnisa, Ulupui, Zakaria, Suryarini}

Bank Risk Profile and Credit Growth in Indonesia

significant effect on bank profitability (Fahrul \& Rusliati, 2018). Market risk, represented by the ratio, Net Interest Margin (NIM) indicates that an increase in interest rates in the banking system in Indonesia can increase bank profitability. This is because one of the main incomes of the bank is through lending and in the credit channelling mechanism there is interest charged by banks to their debtors (Fahrul \& Rusliati, 2018). Liquidity risk, which is reflected in the value of the LDR ratio, affects profitability because the level of liquidity will affect the level of trust of stakeholders, especially customers.

Haryati \& Kristijadi (2016) found that the risk profile did not have a significant effect on the company's performance or financial performance. During the research period, the risk profile of the study sample showed an average reduction in the level of liquidity and operational risk. However, the market and credit risks increased slightly. The absence of the influence of the risk profile on the company's financial performance is possible because the risk profile measurement method uses data available in bank statements. The risk profile should also be measured by calculating future risks that banks may face (Haryati \& Kristijadi, 2016).

This study develops three hypotheses to find the effect of bank's risk profile to bank's credit growth. The first hypothesis found out the effect of credit risk to bank's credit growth. Kiplimo \& Kalio (2015) investigate the effect of credit risk management on the performance or condition of loans. The research data was obtained through a survey method with the target respondents, namely managers and credit officers. This research shows that one form of credit risk management is carried out by assessing clients or debtors. Debtor assessment when applying for credit that is done properly is proven to improve the performance of the credit channel, in this case, the credit channelled can be avoided from a bad condition. In other words, this research proves that credit risk management has an impact on the performance of credit extended by banks (Kiplimo \& Kalio, 2015). Other study that compare Asia and US shows that Credit risk significantly influences banks profitability (Abbas et al., 2019). In Chinese, India and Africa banks, credit risk affects and influences banks performance (Ali \& Dhiman, 2017; Annor \& Obeng, 2018; Gadzo et al., 2019; Munangi \& Sibindi, 2020; Stanley Isanzu, 2017).

Previous research has shown that credit risk does not affect profitability, which is reflected in the rate of return on assets (Fahrul \& Rusliati, 2018). This research is in line with other research which shows that inherent risk which is a calculation of the eight aspects of banking risk does not affect banking (Cahyaningtyas et al., 2017). Other research shows that credit risk influences banking performance in Turkey, the bank's performance is measured through stock return volatility (Ekinchi, 2016). There are differences from the research results above, so this study wants to examine credit risk on credit growth. Based on previous research, we hypothesized that credit risk affects banking credit growth. Banks that can manage credit risk well are reflected in their low level of non-performing loans. A low level of non-performing loans will make banks channel higher credit to their borrowers.

$\mathrm{H}_{1}$ : Credit risk affects banking credit growth

The second hypothesis is to found out the effect of market risk to bank's credit growth. Hutabarat \& Fitrawaty (2018) investigate the effect of asset growth, profitability, and capital structure on firm value through the level of risk. Profitability and level of risk has negative effect to firm value. Growth and the level of risk has negative effect to firm value. Capital structure and risk level have a positive influence on firm value Hutabarat \& Fitrawaty (2018). Fahrul \& Rusliati (2018) investigate the effect 


\section{Gurendrawati, Khairunnisa, Ulupui, Zakaria, Suryarini}

Bank Risk Profile and Credit Growth in Indonesia

of credit risk, market risk, operational risk, and liquidity risk on the profitability of banks listed on the Indonesia Stock Exchange (IDX) from 2010-2014. The sample of banks used was 30 banks and the analysis method used was multiple regression. The results showed that credit risk did not affect partially on profitability. Market risk, operational risk, and liquidity risk have a significant effect on profitability (Fahrul \& Rusliati, 2018). Another finding shows that Market risk in this study is measured through the indicator of floating foreign exchange (FX). The results of this study prove that credit risk and market risk have a significant positive effect on bank profitability as measured by stock return volatility (Ekinchi, 2016).

The stability of bank exchange rates is reflected in the Net Open Position (NOP). Market risk is also related to interest rate risk and credit default swaps. Market risk, which is reflected in the net interest margin, is proven to affect bank profitability as measured by return on assets (Fahrul \& Rusliati, 2018). The inherent risk value, which is a calculation of the eight aspects of banking risk, does not affect banking (Cahyaningtyas et al., 2017). There are differences from the results of the above research, so this study wants to examine market risk on credit growth. Based on previous research, we hypothesized that market risk affects banking credit growth. Market risk as measured by the net open position ratio provides information on the management of foreign currency by banks. Management of the ratio of net open position of banks in Indonesia is expected to be at a maximum of $20 \%$. Management of foreign currency by banks certainly affects the profit and loss on foreign exchange or profitability and will also affect bank lending.

$\mathrm{H}_{2}$ : Market risk affects banking credit growth

The third hypothesis is to found out the effect of liquidity risk to bank's credit growth. Several studies have also examined the effect of liquidity risk on credit growth rates. Loan to Deposit Ratio (LDR) has a significant effect on the growth of Small Medium Enterprises (SME) lending at Regional Development Banks in Indonesia (Isnurhadi et al., 2015). The NPL ratio does not have a significant effect on SME lending to Regional Development Banks in Indonesia (Isnurhadi et al., 2015). In this study, there was no further explanation regarding the reasons for the research findings. Cahyaningtyas et al., (2017) proved that the bank risk profile is following the level of capital adequacy required by Bank Indonesia. Corporate governance has a positive effect on firm value. However, the risk profile represented by inherent risk does not affect firm value. The absence of influence between the bank's risk profile on firm value is possible because the indicator used is the final result of the risk profile, which opens the value of the eight risk profiles (Cahyaningtyas et al., 2017). The decrease in internal bank funds will make it difficult for the bank when liquidity is tight (Ozdemir, 2020). Other studies prove bad loan affect he bank's liquidity (Vodová, 2013).

The condition of bank liquidity affects the financial health of the bank (Babarinde et al., 2020). Liquidity risk is the risk of a bank's inability to meet all obligations due to liquid assets that can be used as collateral or a source of cash flow funding without disturbing the bank's financial condition and activities. Liquidity risk has a significant effect on company performance (Fahrul \& Rusliati, 2018; Hakimi \& Zaghdoudi, 2017). The inherent risk value, which is a calculation of the eight aspects of banking risk, does not affect firm value (Cahyaningtyas et al., 2017). Other finding shows that liquidity risk does not significantly influence of bank performance (Muriithi \& 


\section{Gurendrawati, Khairunnisa, Ulupui, Zakaria, Suryarini}

Bank Risk Profile and Credit Growth in Indonesia

Waweru, 2017). There are differences from the results of the above research, so this study examines the risk of liquidity on credit growth.

$\mathrm{H}_{3}$ : Liquidity risk affects banking credit growth

This study is different from previous studies because this study focuses on contributing to the development of the literature on banking risk profiles and credit growth. This study investigates the main banking risks, namely credit risk, liquidity and market risk on credit growth. Indonesia is one of the countries with the largest human population in the world so banking is an important industry in Indonesia. This study is important to conduct because it contributes suggestion for government and banks in risk management due to manage the bank's credit growth.

\section{Research Method}

The population of this study is conventional commercial banks listed on the Indonesia Stock Exchange (BEI). The choice of conventional banks is due to Bank Indonesia's Regulation / PBI Number 13/1 / PBI / 2011, which regulates the soundness level of commercial banks that carry out conventional activities. The study used purposive sampling as a data collection technique to make it relevant to the research objectives. The data of this study are sourced from secondary data, namely data from bank financial reports accessed through the website company's official the IDX. We observed 37 conventional commercial banks in IDX as research samples that listed in IDX and provide complete annual reports from 2016, 2017, and 2018.

Data collection techniques are through data searches, both annual reports and annual financial reports from existing sources. The source of data search is through the internet / online, namely through the official website of the company being sampled and the official website of the IDX.

This dependent variable is credit growth through the calculation of growth in general, which is to compare the amount or balance of a certain item compared between the current year balance and the previous year. Credit risk as independent variable which measured by total non-performing loan divided by total loan, we called NPL. Market risk as independent variable was measured by net open position ration that given in bank annual report, we call it NOP. Liquidity risk as independent variable was measured by loan to deposit ratio; we call it LDR.

Data processing in this study uses panel data regression with $E$ Views 8 . The stages in processing panel data are choosing the best model between the Common Effect Model (CEM), Fixed Effect Model (FEM), and Random Effect Model (REM). The selection of the best model used the Chow Test, Hausman Test and Lagrange Multiplier Test. After selecting the best model, we tested the classical assumptions and made interpretations of the hypothesis testing of the selected model.

\section{Result and Discussion}

First, we conduct the descriptive analysis to determine the characteristics of the variables in the study. The descriptive measure in the study shows values than consist of mead, median, maximum, minimum, and standard deviation (Wati, 2018). 
Gurendrawati, Khairunnisa, Ulupui, Zakaria, Suryarini

Bank Risk Profile and Credit Growth in Indonesia

Table 1. Descriptive Statistics of the Research Sample

\begin{tabular}{lcccc}
\hline $\begin{array}{l}\text { Statistical } \\
\text { Value }\end{array}$ & $\begin{array}{c}\text { Credit } \\
\text { Growth }\end{array}$ & $\begin{array}{c}\text { Loan to Deposit } \\
\text { Ratio (LDR) }\end{array}$ & $\begin{array}{c}\text { Non-Performing } \\
\text { Loan (NPL) }\end{array}$ & $\begin{array}{c}\text { Net Open } \\
\text { Position (NOP) }\end{array}$ \\
\hline Mean & 0,067849 & 0,864733 & 0,019085 & 0,015425 \\
Median & 0,071396 & 0,867471 & 0,017000 & 0,007200 \\
Maximum & 0,999163 & 1,4526 & 0,063700 & 0,197000 \\
Minimum & $-0,551796$ & 0,41990 & 0,00000 & 0,00000 \\
Standard & 0,169427 & 0,260329 & 0,012749 & 0,024601 \\
Deviation & & & & 111 \\
Observation & 111 & 111 & 111 & 111 \\
\hline
\end{tabular}

Source: Processed Data, 2019

Based on Table 1., there is information that the mean value of credit growth is 0.067849 . Credit growth is the variable $Y$ in the study which represents the trend of credit growth from the sample banks. Meanwhile, the median of credit growth credit is 0.071396 , this median value shows that the mean growth trend of a bank is an upward trend, meaning that the credit year $(n)$ is higher than the year $(n-1)$. The value credit growth highest at 0.999163 which is the trend of increasing credit from Bank Woori Saudara Indonesia 1906 in the year 2018.

For the independent variable as measured by the LDR, the mean LDR is 0.864733 . Meanwhile, the highest value of the LDR ratio is 1.4526 or $145.26 \%$ which is the ratio of Bank Woori in 2018. This is because the distribution of funds in the form of a credit to customers is greater than the collection of public funds through third-party funds. The minimum value of LDR is 0.41990 which is the ratio of Bank Mitraniaga in 2018, the collection of funds in the form of third party funds at the bank is greater than the distribution to the public in the form of credit.

For independent variable which is measured by NPL, the average value of the NPL ratio or bad credit is 0.019085 or $1.9085 \%$. The median value for the bad credit ratio of this research sample is $1.7 \%$. Meanwhile, the highest value of the bad credit ratio is $0 \%$, which is the ratio of Nobu National Bank in 2016. Meanwhile, the ratio of bad credit / NPL net is 0.0637 . For variable $X$, which is measured by the ratio of the net open position, it has an average value of 0.015425 . Meanwhile, the mean net open position ratio of the sample of this study was 0.0072 . The highest value of the ratio of the net open position is 0.197 and the lowest value of the ratio of the net open position is 0 .

Second, we select the best model of our panel data by conducting Chow test, Hausman test, and Langrange Multiple test. At the end of each test we compare the result to choose the best model. The Chow test is a test to determine the best model between FEM and CEM. the hypothesis used is if the p-value (Cross-section chi-square) $>0.05$, meaning that $\mathrm{HO}$ is accepted and the approach used is the Common Effect Model. Conversely, if the $\mathrm{p}$-value (Cross-section chi-square) $<0.05$, then $\mathrm{HO}$ is rejected and the Fixed Effect Model is used as the best model. Based on the Chow test, the

Table 2. Model Selection

\begin{tabular}{llll}
\hline & \multicolumn{1}{c}{ Test } & \multicolumn{1}{c}{ Value } & Conclusion \\
\hline Chow Test & Cross-section chi-square & 0.0051 & FEM is best \\
Hausman Test & Probability Cross Section Random & 0.7982 & REM is best \\
\hline
\end{tabular}

Source: Processed Data, 2019 
Gurendrawati, Khairunnisa, Ulupui, Zakaria, Suryarini

Bank Risk Profile and Credit Growth in Indonesia

Table 3. Multicollinearity Test

\begin{tabular}{lrrr}
\hline & Coefficient Variance & Uncentered VIF & Centered VIF \\
\hline NPL & 1.306 & 3.244 & 1.003 \\
NOP & 0.353 & 1.402 & 1.004 \\
LDR & 0.003 & 12.13 & 1.004 \\
\hline
\end{tabular}

Source: Processed Data, 2019

probability obtained from the LM test is 0.0051 , which is that this probability value is below 0.05 so that $\mathrm{H}_{0}$ is rejected. If $\mathrm{H}_{0}$ is rejected, then $\mathrm{H} 1$ is accepted, then the conclusion is that at the Chow Test stage the better model is the model Fixed Effect.

The value of the centred VIF for NPL, NOP, and LDR is less than 10. From the existing multicollinearity testing, it can be concluded that there is no deviation from the classic multicollinearity assumption, in other words there is a linear relationship between NPL, NOP and LDR in the regression model.

Fourth, we do the panel data regression analysis to determine the regression equation, the effect of each independent variable on the coefficient of determination, and the $F$ value.

The coefficient of determination adjusted $R$ square essentially measures how much ability the research model in explaining the variation of dependent variables (Wati, 2018). The coefficient of determination is between 0 and 1 . An adjusted $R$ square value of ${ }^{2}$ the small ones shows the ability of the independent variables to explain the variation in the dependent variable, which is very limited (Wati, 2018). $R$ Square value close to 1 means that the independent variables provide almost all the information needed to predict the dependent variable. The coefficient of determination reflected by adjusted $R$ Square in this study is 0.189716 . This means that all independent variables in this study can explain the dependent variable by $18.9716 \% .81 .0284 \%$ of credit growth is explained by other variables outside this study. NPL's probability value is 0.0069 means that NPL has a significant effect on bank credit growth in a negative direction. One of the risks that are managed by banks in Indonesia is credit risk. According to the Financial Services Authority Regulation No.75/POJK.03/2016, credit risk is a risk that arises as a result of the failure of other parties to complete their obligations to the bank. One type of credit risk is the debtor's inability to pay off obligations to creditors, namely banks. To ensure credit risk is well managed by banks in Indonesia, OJK requires these banks to report credit risk once a month.

According to the Financial Services Authority Regulation No.15/POJK.03/2017, one indicator of a bank's condition is in danger is the presence of a non-performing loan ratio or NPL above 5\%. The NPL ratio is obtained from the comparison between non-performing loans (after deducting the allowance for losses on receivables) and

Table 4. Hypothesis Testing with Panel Data Regression

\begin{tabular}{lllll}
\hline & Coefficient & Std. Error & t-Statistic & Sig. \\
\hline NPL & -3.472686 & 1.259134 & -2.757996 & 0.0069 \\
NOP & 2.002883 & 0.599981 & -3.338242 & 0.0012 \\
LDR & 0.161454 & 0.057606 & 2.80204 & 0.0060 \\
\hline Adjusted R -Square & & & 0.189716 \\
F Statistic & & & & 9.506914 \\
F Significant & & & & 0.000013 \\
\hline
\end{tabular}

Source: Processed Data, 2019 


\section{Gurendrawati, Khairunnisa, Ulupui, Zakaria, Suryarini}

Bank Risk Profile and Credit Growth in Indonesia

total loans (after deducting the allowance for receivables losses).

Rai \& Purnawati (2017) prove that NPL does not have a significant effect on credit growth. With the high amount of bad credit experienced by a bank, the funds available at the bank for distribution should be less. However, in this study, it was found that high NPLs did not cause banks to be less in channelling credit. Bank lending is also caused by high third party funds. The high level of third party funds is the reason for banks to continue to extend credit to the public.

Roring (2013) found that higher the NPL, the higher the level of credit risk that must be accepted by banks. High credit risk causes a reduction in the bank's capital. Capital is an important factor in bank credit expansion. Hasyim (2014) proved that there is no direct effect of NPL on bank capital adequacy. However, that study also proved that NPL has an effect on commercial bank lending. The impact of NPL on bank lending is because large NPL will cause large reserves for credit losses so that the funds channelled through credit are small.

This study proves that there is a significant influence between credit risk and credit growth. When viewed from the perspective of the company as a debtor, there are many reasons used as the basis for using a bank's credit services. Of course, a low NPL level is a debtor's hope for applying for credit to a bank. A low NPL level proves that a bank can manage its credit risk to a certain level. By properly managing NPL risk, it is hoped that banks will not lose their allocation to continue channelling credit. Debtors may consider credit risk to decide which bank to target in applying for credit.

The presentation of credit risk in bank financial reports is not merely for fulfilling the obligations of regulators, but rather the transparency of information for users of financial reports for decision making. The data in this study indicate that in 2016, all the banks sampled in this study had an NPL ratio below $5 \%$. Meanwhile, $27 \%$ of companies experienced a decline in credit growth in 2016. In 207, there was one bank that had an NPL above the limit set by BI, but in 2017 there was an improvement in the rate of credit growth. This is evidenced by the decline in the number of banks with negative credit growth rates from $27 \%$ to $14 \%$. In 2018, the bank improved its performance as evidenced by the achievement of an NPL ratio of below $5 \%$. The number of banks that have negative credit growth is also stagnant, the same as in 2017. Good credit risk management proves that banks can collect bank funds channelled through credit. Credit is a significant asset owned by a bank so that the risk management of credit is the main focus of the bank. In the 2016-2018 period, the level of consumption of the Indonesian people is still relatively strong, so the urge to use bank credit is still high.

NOP's probability value is 0.0012 means that NPL has a significant effect on bank credit growth in a positive direction. Market risk is the risk that exists in both off and on balance sheet positions due to changes in overall market conditions. Those that affect market risk are interest rates, exchange rates, and equity. This study uses NOP as a reflection of the banking market risk. The exchange rate, which is one of the market risks, will affect the value of the NOP ratio of banks in Indonesia. NOP is the difference between assets and liabilities both on the balance sheet in foreign currency as well as off-balance sheet for each foreign currency stated in rupiah. Banks that can manage a good level of market risk will be able to attract customers and investors, of course.

NOP is proven to affect the profit growth rate of national private commercial banks in Indonesia (Aprilia et al., 2017). Good NOP management results in banks being 


\section{Gurendrawati, Khairunnisa, Ulupui, Zakaria, Suryarini}

Bank Risk Profile and Credit Growth in Indonesia

able to avoid foreign currency transaction losses presented in their profit and loss statements. This research is in line with this research which proves that the presentation of NOP risk affects credit growth.

Based on research data, in 2016 all the banks sampled had a NOP ratio of below $20 \%$, while there were around $27 \%$ of banks that experienced credit growth. Research data in 2017 shows that the NOP of banks ranges from 0\%-6.95\%. In 2017 there was an improvement in the conditions of credit growth, with $14 \%$ of the total sample banks experiencing negative growth. In 2018, the NOP ratio of the sampled banks ranged from $0 \%-5 \%$ and negative credit growth were still at $14 \%$.

This research shows that the banks used as research samples have NOP which is far below the maximum limit of $20 \%$. In the 2016-2018 period, the rupiah weakened against the dollar, this was also the impact of the financial crisis that hit several countries in the world. If the rupiah continues to weaken, the domestic trade sector which relies on imported products will experience a business slump. This sluggishness in business should allow business actors to experience a decrease in business turnover. A decrease in business turnover will have an impact on reducing the rate of credit demand.

However, with the existing phenomena, this study proves that with the weakening of the rupiah, banks can keep their NOP ratio below the $20 \%$ limit. Good NOP management makes banks tend to be able to manage their profitability. With good management of bank profitability coupled with internal factors of business actors, credit growth remains large.

LDR's probability value is 0.0060 means that NPL has a significant effect on bank credit growth in a positive direction. Risk management is characterized by the value of the loan to deposit ratio (LDR). LDR is the ratio between the distribution of bank funds to bank funds. According to Financial Services Authority Regulation No.75/POJK.03/2016, the liquidity ratio is a risk that arises due to the inability of banks to meet obligations due to cash flows on quality liquid assets or sources of funding without disrupting bank activities. To manage this risk, banks must implement an asset and liability management process.

Roring (2013) proves that LDR has a positive effect on lending. Third-party funds or deposits are a factor that influences lending. Based on the research, the third party funds collected from the community were properly channelled by BPRs in Manado through various credit facilities. So that there is a significant influence between LDR and BPR lending in Manado. The LDR ratio has a significant effect on the growth rate of MSME credit at regional development banks in Indonesia (Isnurhadi et al., 2015). Meanwhile, other research proves that the LDR ratio has no significant effect on the rate of return on banking shares (Ayem \& Wahyuni, 2017).

This study proves that the presentation of the banking profile, namely liquidity risk, has a significant effect on bank credit growth. This indicates that the presentation of the risk profile provides confidence for stakeholders, in this case, the debtor, to assess the bank's ability to meet its obligations using cash flow sources or quality assets.

The data from this study shows that the LDR ratio in 2016 reached the range of $40 \%-110 \%$. Meanwhile, in 2017 , the bank's LDR ratio ranged from $42 \%$ to $111 \%$. In 2018 , the bank's NOP ratio was in the range of $41 \%-145 \%$. Meanwhile, BI advises banks to manage their liquidity risk by maintaining the LDR ratio in the range of $78 \%$ - 


\section{Gurendrawati, Khairunnisa, Ulupui, Zakaria, Suryarini}

Bank Risk Profile and Credit Growth in Indonesia

92\%. From the research data that the banks used as research samples have an upper limit on LDR more than BI / OJK regulations, this indicates that the banks used as research samples conduct more lending than third party fundraising. The presentation of liquidity risk helps users of financial statements, namely business actors to assess the health of a bank.

The implications of this research can be used for regulators, especially for OJK, one of which is by optimizing risk management for banks. OJK already has regulations for banks for risk management reporting for banks, however, these regulations should be implemented in accordance with written regulations.

\section{Conclusion}

This study aims to investigate and analyse the effect of risk presentation profile on credit growth. The sample in this study was a commercial bank that met the criteria for the research sampling. The data in this study are secondary data taken from the website company's official and the Indonesia Stock Exchange.

Data processing in this study uses the panel data regression method using $\mathrm{E}$ Views 8 . We conclude that credit risk measured using NPL has a significant effect on credit growth. Market risk measured using by NOP has a significant effect on credit growth. Liquidity measured using by LDR risk has a significant effect on credit growth. This study provides empirical evidence that the main risk of banking affects credit growth. Banking as a significant sector needs to pay attention to risk management. This is important so that banks continue to gain public trust.

The limitation of this study is the limited range of years in just three years of observation between 2016-2018. During this period, the rupiah has depreciated against the dollar. Using the year under the 2016 range allows further researchers to dig deeper into the impact of presenting the banking risk profile on credit growth. Another limitation of this study is the use of the bank's main risk profile, such as credit risk, market risk, and liquidity risk. The banking risk profile that a bank must present in its financial statements is not limited to these three risks. The limitation of this study is that credit growth is explained more by other factors outside this study than by the independent variables in this study. This is evidenced by the results of the adjusted $R$ square of the study in the range of $18 \%$.

We suggest that commercial banks in Indonesia can manage credit risk, market risk and liquidity risk optimally in accordance with the regulations set out by Bank Indonesia. Managing these three risks properly will help banks to be able to manage credit to debtors. We also suggest that future research will be able to examine other risk profiles, not only credit risk, market risk, and liquidity risk Further research is also expected to be able to use other methods to be able to find and analyze the effect of the risk profile on credit growth. Future studies are expected to be able to extend the observation year which is below 2016. The last is future studies can also use other variable outside the risk profile, given the $\mathrm{R}$ square in the study which shows the number in the range of $18 \%$. 


\section{Gurendrawati, Khairunnisa, Ulupui, Zakaria, Suryarini \\ Bank Risk Profile and Credit Growth in Indonesia}

\section{References}

Abbas, F., Iqbal, S., \& Aziz, B. (2019). The Impact of Bank Capital, Bank Liquidity and Credit Risk on Profitability in Postcrisis Period: A Comparative Study of US and Asia. Cogent Economics and Finance, 7(1), 1-18. https://doi.org/10.1080/23322039.2019.1605683

Ali, L., \& Dhiman, S. (2017). The Impact of Credit Risk Management on Profitability: Evidence from Nepalese Commercial Banks. Journal of Commerce \& Accounting Research, 8(2), 86-92. https://doi.org/10.2139/ssrn.2938546

Annor, E., \& Obeng, F. (2018). Impact of Credit Risk Management on the Profitability of Selected Commercial Banks Listed on the Ghana Stock Exchange. Journal of Economics, Management and Trade, 20(2), 1-10. https://doi.org/10.9734/jemt/2017/36881

Aprilia, U. N., Rahadian, D., \& Firli, A. (2017). Pengaruh Tingkat Kesehatan Perbankan Terhadap Pertumbuhan Laba Pada Bank Umum Swasta Nasional Devisa Di Indonesia Periode 2012-2015. E-Proceeding of Management, 4(3), 2393-2399.

Ayem, S., \& Wahyuni, S. (2017). Pengaruh Loan To Deposit Ratio, Capital Adequacy Ratio, Return On Asset Dan Non Perfoming Loan Terhadap Return Saham. Jurnal Akuntansi, 5(1), 71-87. https://doi.org/10.24964/ja.v5i1.258

Babarinde, G. F., Abdulmajeed, I. T., Kazeem, A. B., \& Shuaib, A. A. (2020). Liquidity Risk Management and The Performance of Deposit Money Bank in Nigeria. LAPAI International Journal of Management and Social Sciences, 12(1), 1-12.

Cahyaningtyas, S. R., Sasanti, E. E., \& Husnaini, W. (2017). Bank Risk Profile, Good Corporate Governance And Company Values in Banking Companies Go Public in Indonesia. Journal of Economics, Business \& Accountancy Ventura, 20(1), 41-46. https://doi.org/10.14414/jebav.v20i1.759

Ekinchi, A. (2016). The Effect of Credit and Market Risk on Bank Performance: Evidence from Turkey. International Journal of Economics and Financial Issues, 6(2), 427434.

Fahrul, M., \& Rusliati, E. (2018). Credit Risk, Market Risk, Operational Risk and Liquidity Risk on Profitability of Banks in Indonesia. Trikonomika, 15(2), 78-88. https://doi.org/10.23969/trikonomika.v15i2.387

Gadzo, S. G., Kportorgbi, H. K., \& Gatsi, J. G. (2019). Credit Risk and Operational Risk on Financial performance of Universal Banks in Ghana: A Partial Least Squared Structural Equation Model (PLS SEM) Approach. Cogent Economics and Finance, 7(1), 1-16. https://doi.org/10.1080/23322039.2019.1589406

Hakimi, A., \& Zaghdoudi, K. (2017). Liquidity Risk and Bank Performance: An Empirical Test for Tunisian Banks. Business and Economic Research, 7(1), 46-57. https://doi.org/10.5296/ber.v7i1.10524

Haryati, S., \& Kristijadi, E. (2016). the Effect of Gcg Implementation and Risk Profile on Financial Performance At Go-Public National Commercial Banks. Journal of Indonesian Economy and Business, 29(3), 237-250. https://doi.org/10.22146/jieb.6471

Hasyim, D. (2014). Faktor-Faktor yang Mempengaruhi Penyaluran Kredit pada Bank Umum Periode 2008 dan 2012. Jurnal Pendidikan IImu-IImu Sosial, 6(2), 81-89.

Hutabarat, S. H., \& Fitrawaty, E. W. N. (2018). An Analysis of Asset Growth, Profitability and Capital. International Journal of Business and Management Review, 6(2), 2944. 


\section{Gurendrawati, Khairunnisa, Ulupui, Zakaria, Suryarini \\ Bank Risk Profile and Credit Growth in Indonesia}

Peraturan Bank Indonesia Nomor: 13/ 1 /PBI/2011, (2011).

Isnurhadi, Kartika, I., \& Umrie, H. M. A. R. H. (2015). Pengaruh Loan To Deposit Ratio

(LDR), Nonperforming Loan (NPL) Dan Net Interest Margin (NIM) Terhadap

Pertumbuhan Pinjaman Usaha Kecil Dan Menengah. Jurnal Manajemen Dan Bisnis

Sriwijaya, 13(1), 95-104.

Khairani, R. D., \& Dillak, V. J. (2018). Pengaruh Risk Profile , Good Corporate Governance , Earnings Dan Capital (RGEC) Terhadap Return Saham (Studi Kasus Perusahaan Perbankan di Bursa Efek Indonesia tahun 2012-2016). E-Proceeding of Management, 5(1), 811-819.

Kiplimo, K. S., \& Kalio, A. M. (2015). Influence of Credit Risk Management Practices on Loan Performance of Microfinance Institutions in Baringo County. International Journal of Economics, Commerce and Management, 3(10), 2260-2267. https://doi.org/10.5281/zenodo.572281

Munangi, E., \& Sibindi, A. B. (2020). An Empirical Analysis of the Impact of Credit Risk on the Financial Performance of South African Banks. Academy of Accounting and Financial Studies Journal, 24(3), 1-15.

Muriithi, J. G., \& Waweru, K. M. (2017). Liquidity Risk and Financial Performance of Commercial Banks in Kenya. International Journal of Economics and Finance, 9(3), 256-265. https://doi.org/10.5539/ijef.v9n3p256

Muthii Wanjohi, S. (2017). The Effect of Financial Risk Management on the Financial Performance of Commercial Banks in Kenya. International Journal of Finance and Banking Research, 3(5), 70. https://doi.org/10.11648/j.ijfbr.20170305.12

Otoritas Jasa Keuangan. (2018a). Laporan Profil Industri Perbankan.

Otoritas Jasa Keuangan. (2018b). Statistik Perbankan Indonesia 2018.

Ozdemir, N. (2020). Liquidity Risk Management of Affiliated Banks Duringthe Sub-Prime Mortgage Crisis. The Review of Finance and Banking, 12(1), 31-47. https://doi.org/10.24818/rfb.20.12.01.03

Rai, I. A. A., \& Purnawati, N. K. (2017). Faktor - Faktor Yang Mempengaruhi Kredit Pada Bank. E-Jurnal Manajemen Universitas Udayana, 6(11), 5941-5969.

Roring, G. D. J. (2013). Analisis Determinan Penyaluran Kredit oleh Bank Perkreditan Rakyat (BPR) di kota Manado. Jurnal EMBA, 1(3), 1030-1040.

Stanley Isanzu, J. (2017). The Impact of Credit Risk on the Financial Performance of Chinese Banks. Journal of International Business Research and Marketing, 2(3), 1417. https://doi.org/10.18775/jibrm.1849-8558.2015.23.3002

Vodová, P. (2013). Determinants of Commercial Banks' Liquidity in Poland. Proceedings of 30th International Conference Mathematical Methods in Economics, 962-967.

Wati, L. N. (2018). Metodologi Penelitian Terapan: Aplikasi SPSS, EVIEWS, Smart PLS, dan AMOS. Mujahid Press. 